\title{
Eruption and emplacement of the Yamakogawa Rhyolite in central Kyushu, Japan: A model for emplacement of rhyolitic spatter
}

\author{
Kuniyuki Furukawa and Hiroki Kamata \\ Department of Dynamics of the Earth Environment, Graduates School of Human and Environmental Studies, \\ Kyoto University, Sakyo-ku, Kyoto 606-8501, Japan
}

(Received October 30, 2003; Revised April 5, 2004; Accepted April 5, 2004)

\begin{abstract}
The Yamakogawa Rhyolite, which erupted in the early Quaternary period in central Kyushu, Japan, comprises seven units, three contain of which spatter and stretched pumice. Our fieldwork shows that these are the deposits of strombolian fire-fountains and rheomorphic tuff. Such deposits derived from silicic magma have been previously described and still are controversial. Some of the reasons given for their formation were exclusively peralkaline composition and high-magmatic temperature. The chemical analyses of the Yamakogawa Rhyolite show nonperalkaline composition and low-magmatic temperature. Moreover, the mineral assemblage of the Yamakogawa Rhyolite suggests that its water content was indistinguishable from other rhyolitic deposits. This is the first report that demonstrates that eruption of silicic magma as fire-fountain and pyroclastic flow with rheomorphism is not, necessarily, restricted to peralkaline composition, high-magmatic temperature and low-water content rhyolite.
\end{abstract}

Key words: Rhyolite, lava, spatter, strombolian, Kyushu.

\section{Introduction}

Silicic magma in general has been observed and interpreted to erupt as lava domes or large-scale pyroclastic flows associated with caldera forming events (e.g., Hildreth, 1979; Nakada and Fujii, 1993). These eruption styles have been attributed to the high viscosity of silicic magma. However, in some cases, silicic magma has been interpreted as erupting and behaving as low viscosity magma, such as basaltic magma (e.g., Branney et al., 1992; Stevenson et al., 1993) and the products are interpreted as spatter deposits and rheomorphic pyroclastic deposits (terminology after Branney et $a l .$, 1992). In general, spatter is produced by strombolian and Hawaiian style fountaining events and deposits are characterized by fountain-fed (clastogenic) lavas and spatter cones and ramparts such as 1986 eruption of Izu-Oshima volcano (Sumner, 1998). Spatter rich pyroclastic flows have also been described by Mellors and Sparks (1991) and Valentine et al. (2000). Fountaining events producing spatter are typical of mafic to intermediate low viscosity magmas. The question remains as to why silicic magma occasionally exhibits low viscosity behaviors. Three main reasons for silicic magma exhibiting low viscosity behavior have been documented; these are (a) peralkaline composition magma (Mahood, 1986), (b) high-magmatic temperature (Henry et al., 1989), and (c) low-water content magma (Creaser, 1991).

The Yamakogawa Rhyolite (Kamata, 1985; Aso and Watanabe, 1985), which erupted in the early Quaternary period in central Kyushu, Japan, comprises seven units. Detailed lithofacies studies suggest three of which are strombolian fire-fountain deposits and rheomorphic pyroclastic flow

Copy right(c) The Society of Geomagnetism and Earth, Planetary and Space Sciences (SGEPSS); The Seismological Society of Japan; The Volcanological Society of Japan; The Geodetic Society of Japan; The Japanese Society for Planetary Sciences; TERRAPUB. deposits. The other four units are lava flows and pyroclastic flow deposits. The chemical analyses of these seven units show non-peralkaline composition, indicate low-magmatic temperature and the mineral assemblage indicates a water content that is typical for rhyolitic magma.

It is difficult to establish the eruption, transport and emplacement mechanism of the Yamakogawa Rhyolite, because of limited outcrop and because the primary textures are obscured by devitrification and spherulitization. However, the Yamakogawa Rhyolite offers insights into the emplacement history and eruption style of silicic spatter eruptions, because the emplacement mechanisms of such silicic deposits are poorly understood due to lack of examples. Such silicic deposits are recognized in many places in the world, indicating that this problem is not regional, but has a widespread geological occurrence. In this paper, we describe the lithofacies and geochemistry of the Yamakogawa Rhyolite and suggest a model to the eruption and emplacement of silicic spatter.

\section{Geologic Setting}

The Yamakogawa Rhyolite erupted in the early Quaternary period in central Kyushu, Japan (Fig. 1). It is located within the Hohi volcanic zone, which traverses Kyushu Island in an ENE-WSW orientation and was dominated by volcanic activity during the Neogene and Quaternary (Kamata, 1989). The rhyolite, comprising seven units, forming a plateau with a total thickness of $200 \mathrm{~m}$ (Kamata, 1997). The basal part is not exposed. Yamada et al. (2002) reported whole-rock K-Ar ages of $1.22 \pm 0.02$ Ma for the uppermost unit and $1.17 \pm 0.02 \mathrm{Ma}$ for the basal unit of these deposits. We obtained paleomagnetic polarity data from the Yamakogawa Rhyolite in order to confirm the validity of the $\mathrm{K}$-Ar age, and a single reversed polarity is observed from the entire unit. From the K-Ar ages and the paleomagnetic 


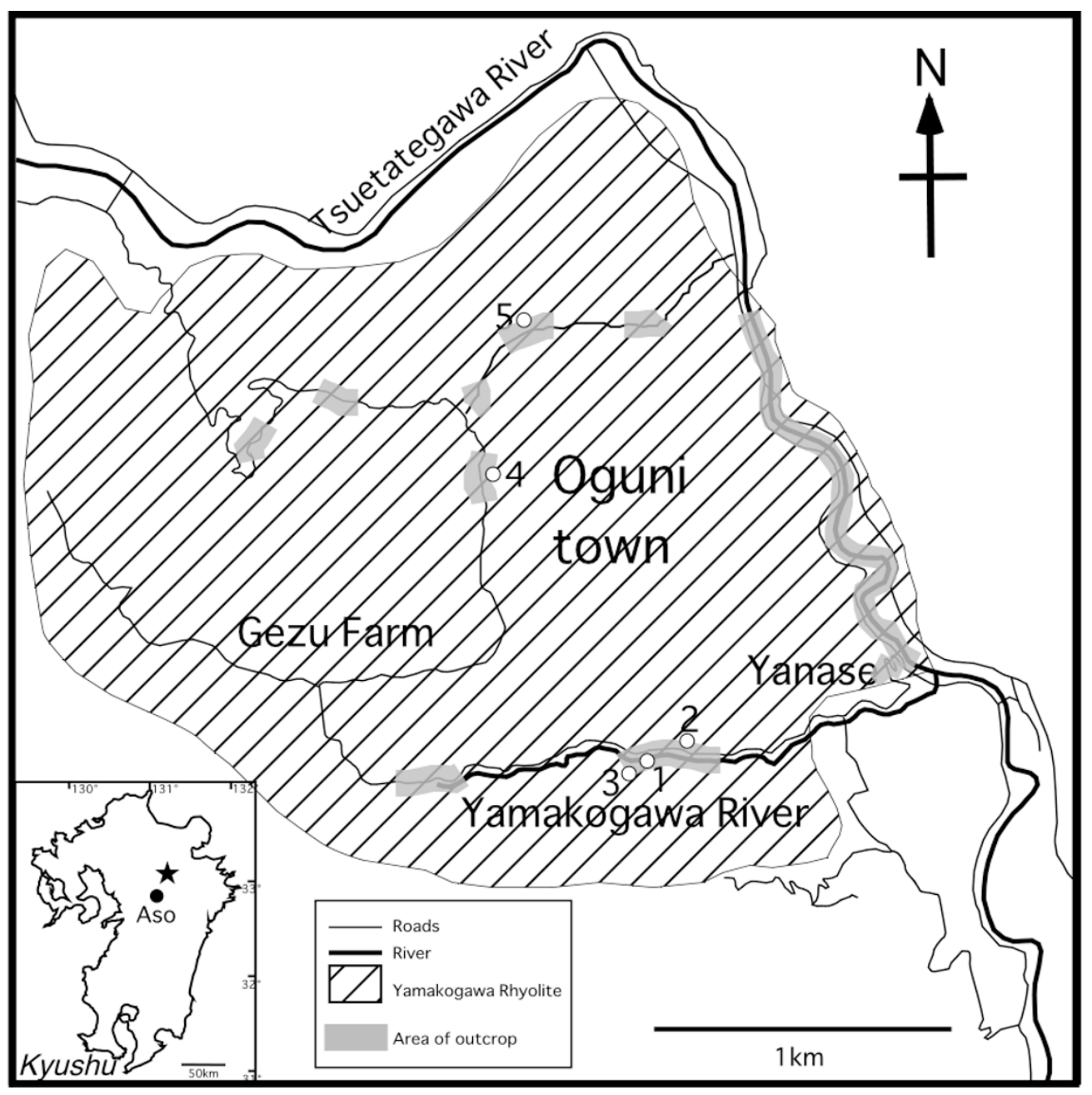

Fig. 1. Index map showing location of the Yamakogawa Rhyolite in middle Kyushu, Japan (distribution of the Yamakogawa Rhyolite is modified from Kamata (1997)). Inset figure shows the locality of the outcrops. The outcrops are mainly exposed along the Yamakogawa and the Tsuetategawa Rivers.

Table 1. Whole-rock analyses of the Yamakogawa Rhyolite and mineral composition for geothermometry.

\begin{tabular}{|c|c|c|c|c|c|c|c|c|c|c|}
\hline & Unit A & Unit B & Unit C & Unit D & Unit E & Unit G & $\begin{array}{c}\text { Unit A } \\
\text { hb }\end{array}$ & $\mathrm{pl}$ & $\mathrm{mt}$ & il \\
\hline$\overline{\mathrm{SiO}_{2}}$ & 75.89 & 68.44 & 70.71 & 74.23 & 74.25 & 74.27 & 44.16 & 58.13 & 0.68 & 0.03 \\
\hline $\mathrm{TiO}_{2}$ & 0.16 & 0.35 & 0.35 & 0.17 & 0.16 & 0.18 & 2.27 & 0.01 & 13.11 & 48.97 \\
\hline $\mathrm{Al}_{2} \mathrm{O}_{3}$ & 13.79 & 16.81 & 15.77 & 14.49 & 13.93 & 13.94 & 9.73 & 26.27 & 4.31 & 0.11 \\
\hline $\mathrm{FeO}^{*}$ & 1.06 & 1.93 & 1.99 & 1.09 & 1 & 0.94 & 12.94 & 0.26 & 69.10 & 45.81 \\
\hline $\mathrm{MnO}$ & 0.05 & 0.09 & 0.06 & 0.07 & 0.06 & 0.05 & 0.43 & 0 & 1.16 & 1.49 \\
\hline $\mathrm{MgO}$ & 0.14 & 0.47 & 0.17 & 0.06 & 0.14 & 0.17 & 14.01 & 0.01 & 0.81 & 1.59 \\
\hline $\mathrm{CaO}$ & 0.92 & 2.34 & 1.50 & 0.74 & 0.75 & 0.93 & 10.85 & 8.67 & 0.06 & 0.02 \\
\hline $\mathrm{Na}_{2} \mathrm{O}$ & 4.17 & 3.95 & 3.51 & 3.52 & 3.56 & 4.00 & 2.36 & 6.08 & 0 & 0 \\
\hline $\mathrm{K}_{2} \mathrm{O}$ & 4.21 & 3.41 & 3.83 & 4.43 & 4.31 & 4.32 & 0.59 & 0.48 & 0.03 & 0.01 \\
\hline \multirow[t]{2}{*}{ Total } & 100.38 & 97.79 & 97.89 & 98.79 & 98.12 & 98.81 & 97.34 & 99.91 & 89.26 & 98.03 \\
\hline & $\begin{array}{c}\text { Unit B } \\
\mathrm{hb}\end{array}$ & pl & $\mathrm{mt}$ & il & $\begin{array}{c}\text { Unit C } \\
\mathrm{hb}\end{array}$ & pl & $\begin{array}{c}\text { Unit D } \\
\mathrm{mt}\end{array}$ & il & $\begin{array}{c}\text { Unit G } \\
\mathrm{mt}\end{array}$ & il \\
\hline $\mathrm{SiO}_{2}$ & 44.98 & 56.50 & 0.06 & 0.01 & 44.70 & 58.05 & 0.16 & 0.01 & 0.05 & 0.01 \\
\hline $\mathrm{TiO}_{2}$ & 2.02 & 0 & 8.27 & 43.54 & 2.31 & 0 & 4.16 & 40.40 & 7.68 & 41.43 \\
\hline $\mathrm{Al}_{2} \mathrm{O}_{3}$ & 9.33 & 26.75 & 2.12 & 0.15 & 9.85 & 26.25 & 2.59 & 1.03 & 1.58 & 0.25 \\
\hline $\mathrm{FeO}^{*}$ & 12.90 & 0.24 & 81.51 & 48.87 & 13.50 & 0.26 & 76.79 & 46.04 & 83.60 & 53.10 \\
\hline $\mathrm{MnO}$ & 0.06 & 0 & 0.06 & 0.19 & 0.07 & 0.01 & 3.37 & 2.93 & 0.16 & 0.15 \\
\hline $\mathrm{MgO}$ & 13.88 & 0.02 & 1.29 & 2.17 & 13.35 & 0.01 & 0.96 & 1.45 & 0.69 & 0.26 \\
\hline $\mathrm{CaO}$ & 10.87 & 9.68 & 0.01 & 0.13 & 10.96 & 8.65 & 0.06 & 0 & 0 & 0 \\
\hline $\mathrm{Na}_{2} \mathrm{O}$ & 1.80 & 6.00 & 0.03 & 0.01 & 2.10 & 6.37 & 0.03 & 0 & 0.03 & 0.02 \\
\hline $\mathrm{K}_{2} \mathrm{O}$ & 0.57 & 0.29 & 0 & 0 & 0.60 & 0.41 & 0 & 0 & 0.01 & 0 \\
\hline Total & 96.41 & 99.48 & 93.35 & 95.07 & 97.44 & 100.01 & 88.12 & 91.85 & 93.79 & 95.22 \\
\hline
\end{tabular}




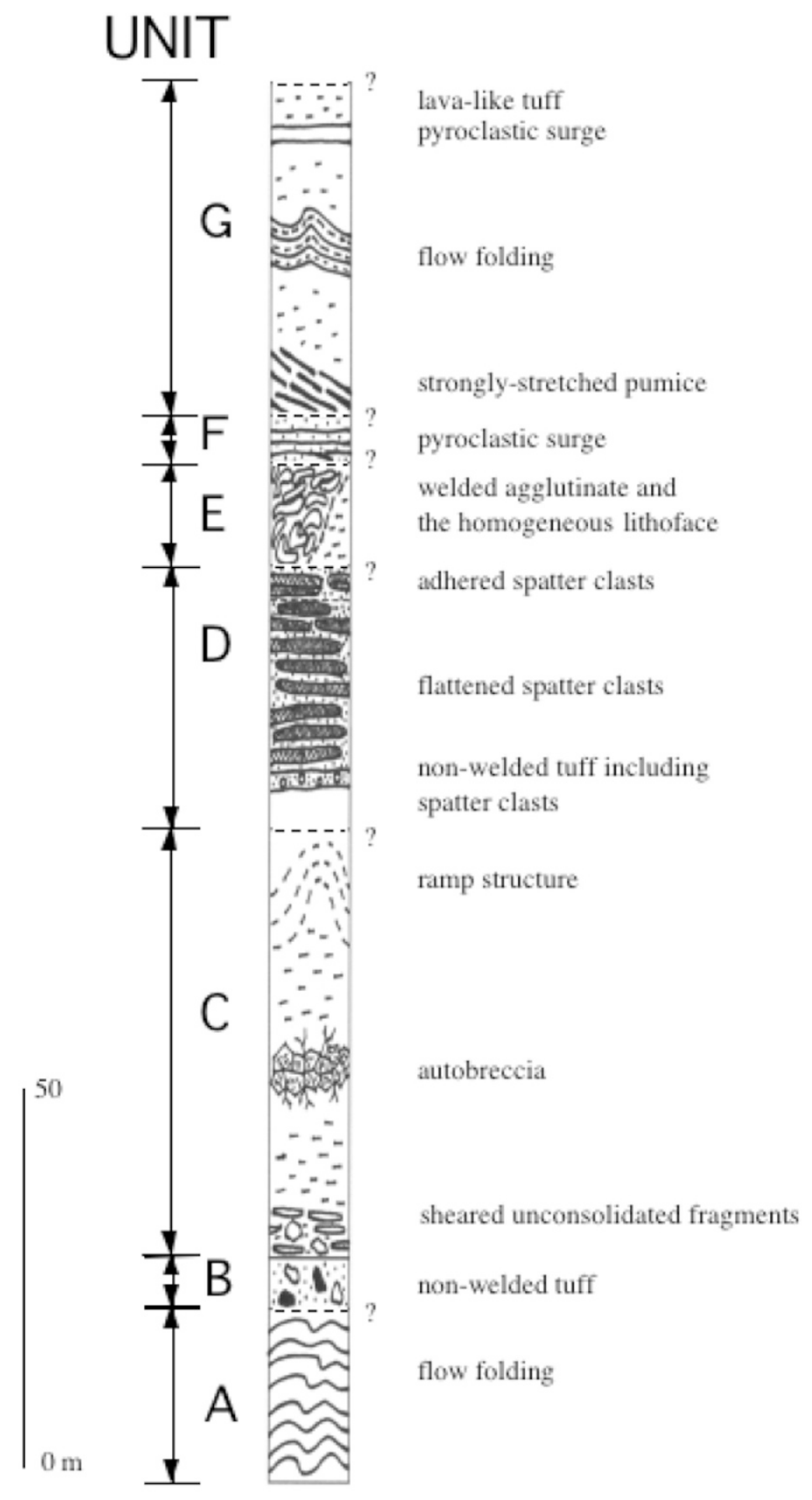

Fig. 2. Schematic section through the Yamakogawa Rhyolite. There are seven units, A to G. Units A and C are lava-flow deposits, and units B and F are non-welded pyroclastic flow and surge deposits. Units C, D, and G are rheomorphic tuff and fire-fountain deposits. Question marks indicate cryptic contact.

data, the Yamakogawa Rhyolite erupted during a reversed polarity interval between the Jaramillo and Cobb Mountain subchrons, which corresponds to the upper part of C1r. 2 (Cande and Kent, 1992). These K-Ar ages and paleomagnetic results show that eruption of the Yamakogawa Rhyolite erupted without significant dormant periods. The Yamakogawa Rhyolite is underlain by the Kamitarumizu Andesite, which gives K-Ar ages of 1.3-1.7 Ma and is a hornblendepyroxene andesite lava (Kamata, 1997). It is overlain by the Aso-4 pyroclastic flow deposit, which erupted from Aso caldera and gives a K-Ar age of 0.09 Ma (Kamata, 1997).

The Yamakogawa Rhyolite is mainly composed of tuffs, lavas and welded-agglutinate deposits. No lateral variation was observed in the lithofacies, because the deposits are poorly exposed, being visible only in road cuttings and on dissected steep slopes along the Yamakogawa and the Tsuetategawa Rivers. However, these steep slopes provide a good opportunity to investigate vertical changes in lithofacies.

\section{The Yamakogawa Rhyolite}

The Yamakogawa Rhyolite is composed of seven units (unit A to $\mathrm{G}$ ) divided into two non-welded deposits and five intensely welded deposits (Fig. 2). Whole-rock chemical analyses show that most of the Yamakogawa Rhyolite is 
(a)

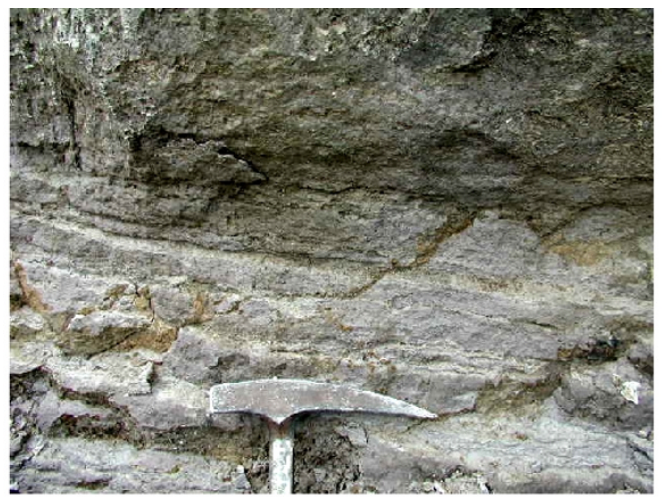

(b)

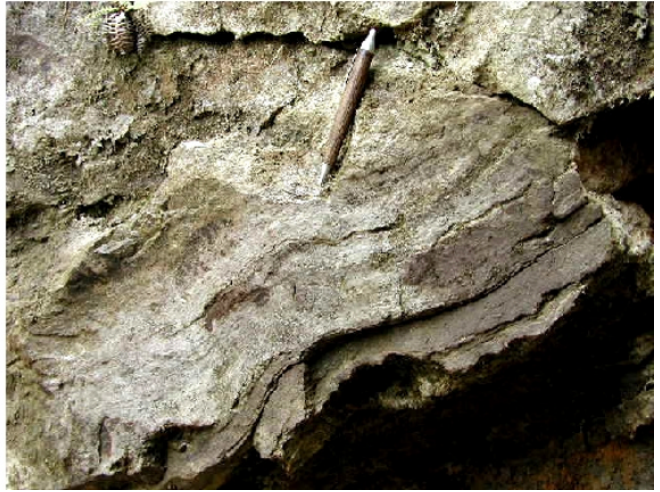

Fig. 3. Representative outcrops of unit D. (a) Streaking is composed of an intensely welded reddish layers alternating with non-welded white layers, the welded layer shows lenticular shape. (b) Adhered clasts indicating clasts were hot and fluidal on deposition.

(a)

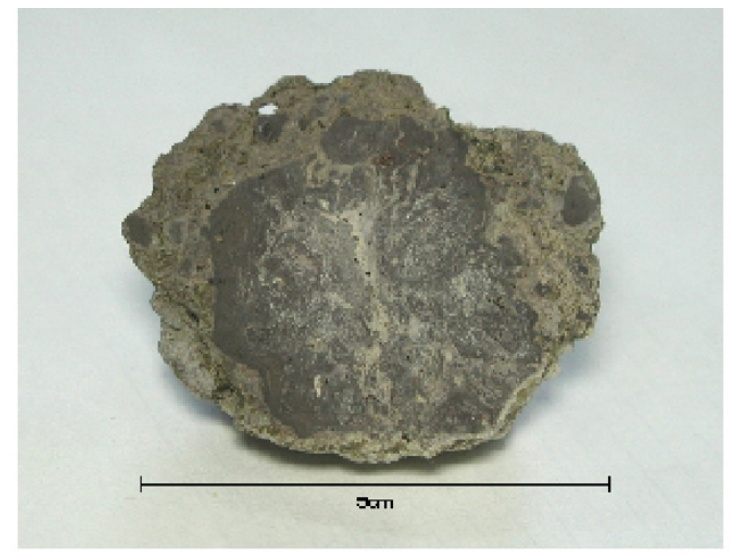

(b)

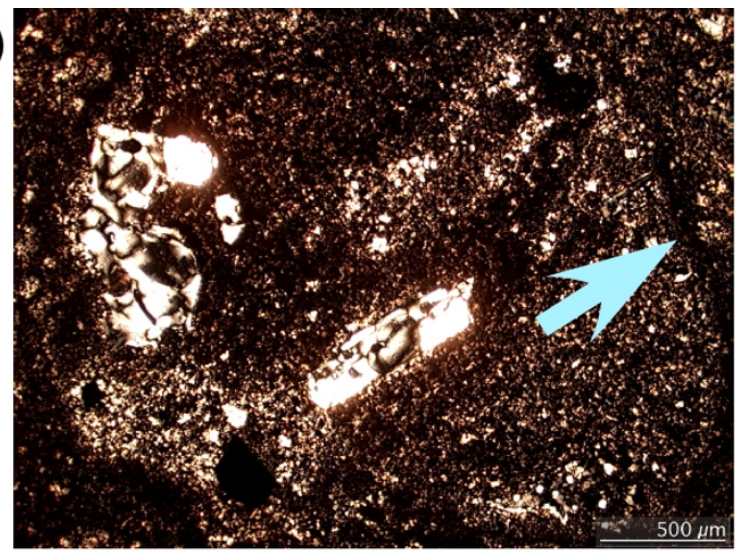

(c)

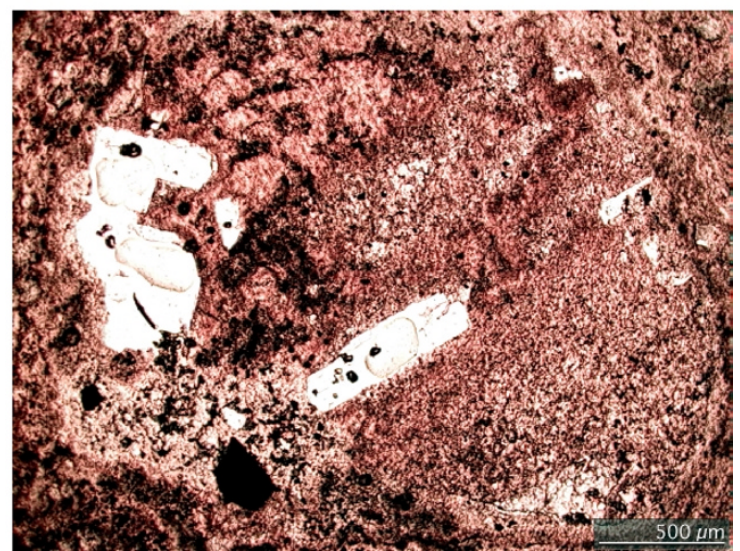

Fig. 4. Cored bomb contained in the subunit of unit D (a). It is $5 \mathrm{~cm}$ in diameter. The center part is composed of an aggregate of discrete clasts (circular and fluidal shapes), and the rim part is volcanic ash. In microscopic observation, the circular clast of the center part has a chilled margin. (b) shows the glassy chilled margin. (b) is crossed polarized light, and (c) is plane polar at the same position.

rhyolitic composition (Unit A, C, D, E, G), with minor dacite (Unit B) (Table 1).

Units $\mathrm{B}$ and $\mathrm{F}$ are non-welded and show stratification, degassing pipes (Aso and Watanabe, 1985), and cross lamination, supporting a pyroclastic flow or pyroclastic surge origin. Units $\mathrm{A}$ and $\mathrm{C}$ are intensely welded and show flow folding and ramp structures suggesting a lava flow origin. There is, however, a possibility that these units are not lava flows: Sumner and Branney (2002) describe similar struc- tures occurring in rheomorphic ignimbrites and propose that their true origin may be discernible only by tracing the lateral and sourceward variations across well-exposed ground.

The eruption style and depositional mechanism of the other three intensely welded deposits (units D, E, and G) are difficult to determine. This is because (1) their primary structures are obliterated by rheomorphism after accumulation, (2) post-depositional devitrification and widespread development of spherulites overprint primary welding textures 
(a)
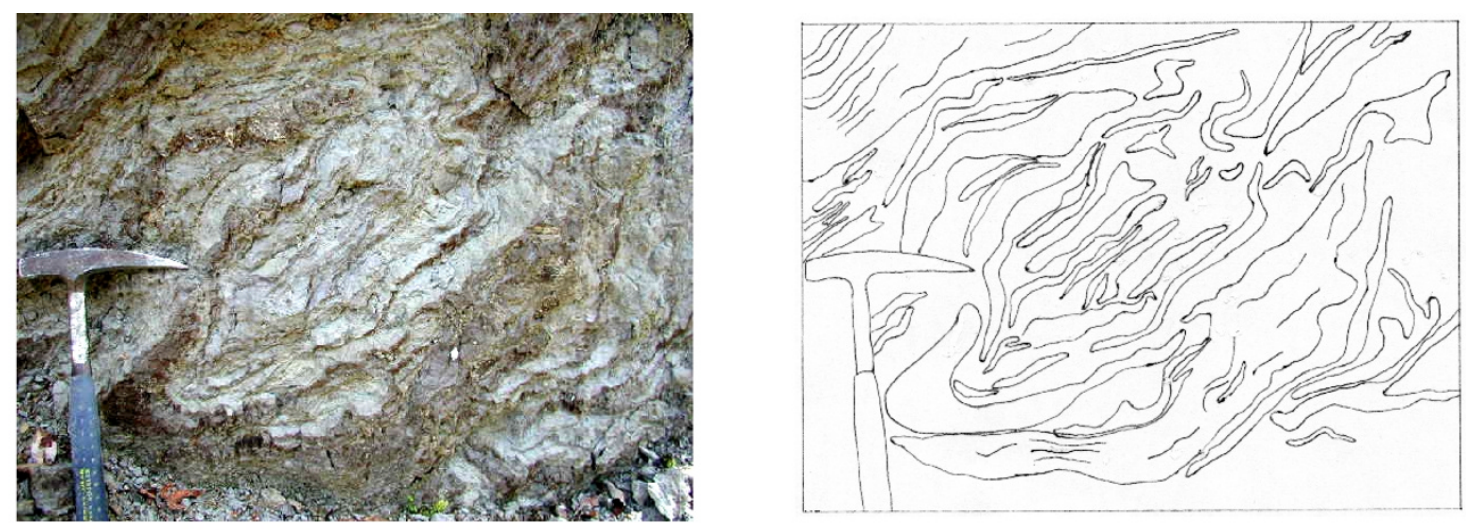

(b)

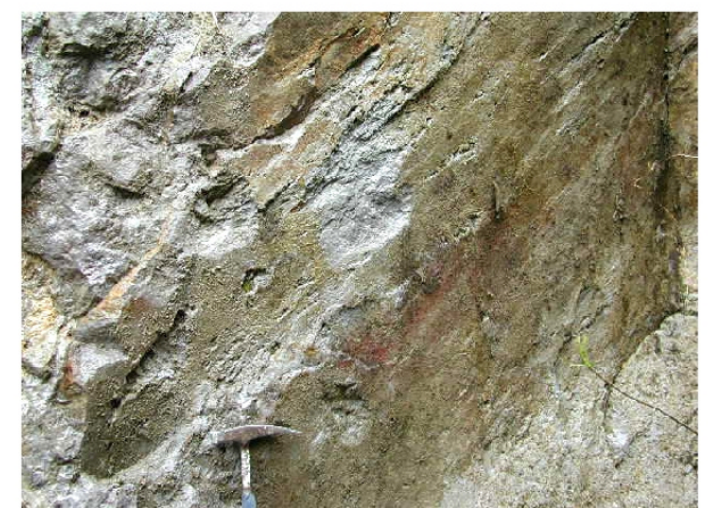

Fig. 5. The outcrop of the unit E. (a) Agglutinate lithofacies, individual spatter clasts are deformed and agglutinated. Right is sketch of this outcrop. (b) Lava lithofacies. There is a gradational transition from agglutinate to lava lithofacies. Left side of the photograph is transitional zone.

and groundmass textures, and (3) observations in the field were thwarted due to lack of good outcrop.

Units D, E, and G, which show enigmatic lithofacies for rhyolitic deposits, are the subjects of this paper.

\subsection{Unit D}

Unit D is at least $80 \mathrm{~m}$ thick; the basal part is not exposed. It is chiefly exposed along the Yamakogawa River. It comprises a welded middle part, an upper non-welded part, and an interbedded non-welded subunit.

The middle part of unit D is massive, non-vesicular and shows streaky texture (Fig. 3(a)) typical of rhyolitic lava flow deposits. The streaking is produced by an alternation of intensely reddish layers and white-altered layers. It shows flow folding, which indicates plastic deformation. In microscopic observation, the phenocrysts are not broken suggesting an effusive rather than an explosive origin.

The upper non-welded part is enigmatic (Fig. 3(b), locality 1). The lithofacies shows non-welded pyroclastic flow deposit with stratification. Included blocks are composed of massive and non-vesiculated lavas. They are typically flattened and partly show ropy structure. Several flattened blocks are adhered like welded agglutinate deposit (Fig. 3(b)), with an appearance similar to the spatter piles presented in Wolff and Sumner (2000, figure 3).

The non-welded subunit is interpreted as an interbedded pyroclastic flow deposit (locality 2). Its thickness is approximately $1 \mathrm{~m}$. This subunit contains several cored bombs approximately $5 \mathrm{~cm}$ in diameter within one outcrop (Fig. 4(a)). These bombs have two parts, the center part is a circularshape block $3 \mathrm{~cm}$ in diameter, and the rim is volcanic ash.
There are two ideas for the formation of circular-shaped blocks in pyroclastic flow deposits: (1) The block was solid and was abraded during transportation. (2) The block was liquid and was deformed during transportation. If the block was solid and rounded by abrasion, it should be homogeneous. However, this block is heterogeneous. It is assemblage of some deformed clasts. The each clasts are approximately $3-5 \mathrm{~mm}$ in diameter. In microscopic observation, they are composed of a glassy rind and crystalline core indicating chilled margin. One of the clasts is shown in Fig. 4(b). This texture is similar to the description for the spatter clasts of Valentine et al. (2000) and Mellors and Sparks (1991). These indicate that the blocks were formed by collision and coalescence of spatter clasts and volcanic ash during transportation.

\subsection{Unit E}

The thickness of unit $\mathrm{E}$ is unknown, because its exposure along the Yamakogawa River is poor due to erosion (locality 3 ). In outcrop, this unit is composed of two laterally intergradational lithofacies (agglutinate lithofacies and lava lithofacies).

(1) Agglutinate lithofacies (Fig. 5(a)): This outcrop is assemblage of clasts showing fluidal, contorted and flattened shapes. The individual clast size is approximately $100 \mathrm{~cm}$ in length and $5 \mathrm{~cm}$ in width. The lithofacies does not show stratification and lacks fine matrix. It indicates that this deposit is not accumulated from lateral flow. In microscopic observation, devitrification has strongly overprinted primary textures. These lithofacies and microscopic features resemble the welded-agglutinate deposit of Taylor Creek Rhyolite 
(a)

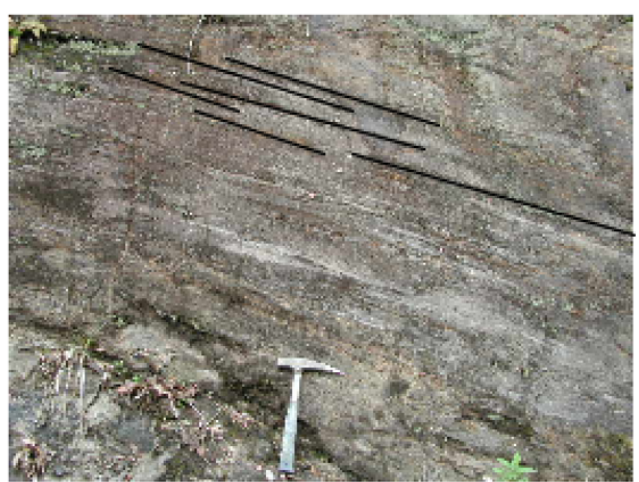

(c)

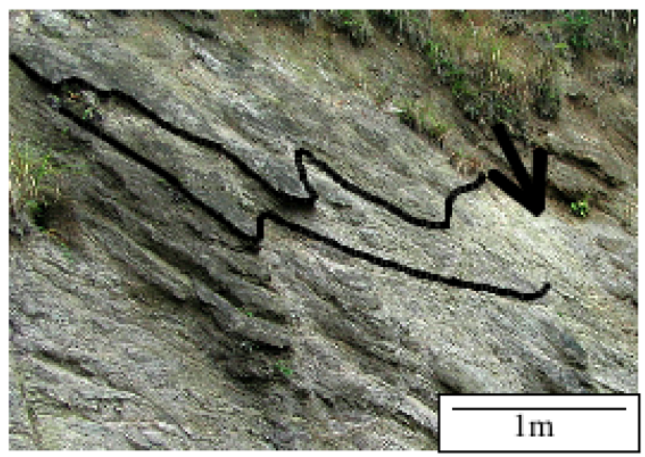

(b)

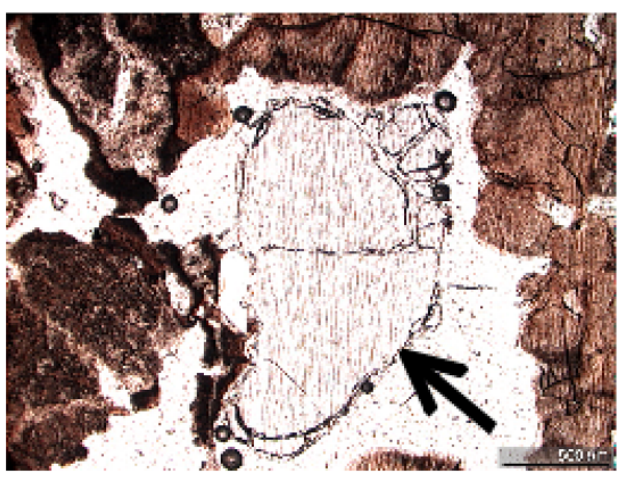

(d)

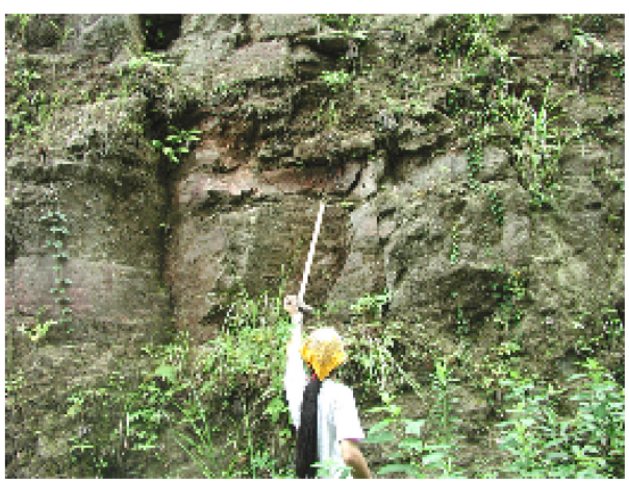

Fig. 6. Representative outcrops of unit G. (a) The basal part, characterized by streaky texture. The black streaks are obsidian, lenticular in form with a length of $<2 \mathrm{~m}$. Examples of obsidian streaks are shown in upper part of the photograph. (b) Photomicrograph (plane polar) of a glass shard in the basal part. Arrow indicates a glass shard surrounded by spherulitic texture in dark color. Streaks in the glass are fibrous vesicles. (c) The middle part of the unit characterized by flow folding. The wavelength is unknown. Examples of folding planes are shown in the photograph. Arrow indicates dipping direction. (d) The upper part, characterized by lava-like lithofacies with interbedded surge deposits. The rod points the surge deposit.

(Duffield, 1990). Therefore, these deformed clasts are interpreted to be fluidal spatter from fallout not pyroclastic flow. (2) Lava lithofacies (Fig. 5(b)): This lithofacies passes gradationally over several tens of cm's from agglutinate lithofacies. It is homogeneous and intensely welded. This lithofacies was probably formed by post depositional welding under the influence of in situ load and cooling rate.

\subsection{Unit G}

Unit $\mathrm{G}$ constitutes the uppermost unit of the Yamakogawa Rhyolite. It is exposed along the road cutting of the north face of the study area and is approximately $50 \mathrm{~m}$ thick.

The basal part is intensely welded, and spherulitization and devitrification prevent an observation of particulate condition. This part is characterized by streaky texture (Fig. 6(a), locality 4). Black lenticular streaks (length of $<2 \mathrm{~m}$ ) are composed of obsidian. This texture is similar to that described by Henry and Wolff (1992), with the obsidian streaks representing highly stretched pumice. In thin section, it is widely spherulitic, however, glass shards (Fig. 6(b)), broken phenocrysts and minor lithic fragments were observed, providing strong evidence of pyroclastic origin.

A detailed investigation of the middle and upper parts was impossible because of limited exposure and weathering (locality 5). The middle part is characterized by flow folding (Fig. 6(c)). Its wavelength is unknown due to lack of outcrop. The upper part comprises lava-like lithofacies, which are intensely welded and lack fiamme (Fig. 6(d)). The im- plication of pyroclastic origin is only from the occurrence of broken phenocrysts and minor accessory fragments. In this part, an interbedded-surge deposit (15 cm thick) is observed (Fig. 6(d)). This may also indicate that this unit is pyroclastic in origin. From these restricted geological and microscopic features, we interpreted that this unit was deposited by a pyroclastic flow and underwent rheomorphism (e.g., Henry and Wolff, 1992).

\section{Geothermometry}

Electron microprobe analyses were performed on the phenocrysts in the least altered part on the Yamakogawa Rhyolite, to determine equilibration temperature, which can influence the mode of eruption.

Phenocrysts of the Yamakogawa Rhyolite are mainly composed of plagioclase, biotite, Fe-Ti oxides, and zircon. Hornblende occurs in the units A, B, and C. From these mineral assemblages, we obtained equilibration temperatures using plagioclase-hornblende geothermometry (Holland and Blundy, 1994) and Fe-Ti oxide geothermometry (Spencer and Lindsley, 1981). The mineral compositions, which were used to calculate equilibration temperatures, are shown in Table 1. The plagioclase-hornblende geothermometry are calculated from average rim compositions of both minerals. On Fe-Ti oxides, we avoided exsolved grains for geothermometry. Most Fe-Ti oxides, however, show significant exsolution. Therefore, calculated results may reflect the effect of subsolidus reequilibration. The results are shown in Ta- 
Table 2. Geothermometry for the Yamakogawa Rhyolite.

\begin{tabular}{lrr}
\hline Unit & hb-pl $\left({ }^{\circ} \mathrm{C}\right)$ & Fe-Ti Oxides $\left({ }^{\circ} \mathrm{C}\right)$ \\
\hline A & 880 & 800 \\
B & 830 & 850 \\
C & 830 & il absent \\
D & hb absent & 780 \\
E & hb absent & 850 \\
\hline
\end{tabular}

hb-hornblende, pl-plagioclace, il-ilmenite.

ble 2. This data shows that the equilibration temperature is approximately $780-880^{\circ} \mathrm{C}$. It shows that the temperature of the Yamakogawa Rhyolite is moderately high compared to typical rhyolitic magma, but not abnormally so. The temperature is consistent with the occurrence of biotite, which cannot exist in high temperature, in all of the units.

\section{Discussion}

\subsection{Emplacement history}

The emplacement histories of the units D, E, and G characterized by rheomorphism and spatter in the Yamakogawa Rhyolite are enigmatic. We propose a model for the emplacement of units D, E, and $\mathrm{G}$ as follows.

The deposits in unit D contain spatter suggesting deposition from fire-fountains. Flattened spatters occur in the middle part and adhered spatter clasts are contained in the upper part and subunit. Based on these lithofacies, two styles of eruption are considered. (1) It was erupted by strombolian fire-fountain, and the spatter is of fallout origin not the product of column collapse and pyroclastic flow. Valentine et al. (2000) reported that ballistically-emplaced strombolian spatter could incorporate ashy material as individual clasts role down cone slopes. In this case the fallout spatter would not be flattened as it is in Unit D. (2) Unit D is the deposit of a spatter-rich pyroclastic flow. If this unit accumulated by progressive aggradation (Branney and Kokelaar, 1992), the flattened spatter is easily explained. When the spatter clasts come into contact with aggradational surface, some ash adheres to them. The spatter is stretched and folded as it is dragged along the aggradational surface by the overriding current. This mechanism is supported by gradational lithofacies change of unit $\mathrm{D}$ into a typical pyroclastic flow deposit, which has an intensely-welded middle part and non-welded upper part. However, determination of progressive aggradation must be done very carefully. In the Yamakogawa Rhyolite, the lateral variation is poorly exposed. Therefore, we cannot assert positively that the deposit was accumulated by progressive aggradation.

The unit $\mathrm{E}$ is assemblage of deformed clasts interpreted as spatter. The lithofacies lacks fine matrix and stratification. These indicate that this unit is not a deposit from a lateral flow. Shape of the each clasts is preserved except for homogeneous part causing post depositional welding. This shows that this deposit is not underwent significant rheomorphism such as fountain-fed lava. From these characteristics, we interpreted that this deposit is welded agglutinate from stromborian fire-fountaining (e.g., Duffield, 1990; Turbeville 1992).
In the unit $\mathrm{G}$, it is difficult to determine the emplacement mechanism because of their poor exposure and weathering. However, keys to determine the mechanism are preserved in the basal part. The basal part is intensely welded. Spherulitization and devitrification prevent an observation of particulate condition. This part includes highly stretched obsidian lens interpreted as pumice origin, very minor glass shards, broken phenocryst and minor lithic fragments. These indicate that this deposit is evidently pyroclastic origin (Henry and Wolff, 1992). Flow folding and lava-like lithofacies are developed in the upper part of this unit. From these characteristics, presumable emplacement mechanism is rheomorphic pyroclastic flow (e.g., Schmincke and Swanson, 1967; Chapin and Lowell, 1979; Branney and Kokelaar, 1992). However, we cannot assert the emplacement mechanism positively because of poor exposure of lateral variation.

From these emplacement mechanisms, we propose the following eruption styles. We envisage that the eruptions as low-playing columns such as a boil-over type pyroclastic flows or strombolian fire-fountains. Smith and Cole (1997) suggested that these types of eruption lose less heat through mixing with atmosphere than plinian columns and temperatures remain high within the resultant pyroclastic flow. By these mechanisms, the Yamakogawa Rhyolite could produce spatter, which could deform plastically during transportation, and pumice, which could be sheared just before emplacement of the pyroclastic flow.

\subsection{Causes of the eruption style}

In general, due to its high viscosity, rhyolitic magma erupted as lava domes and large-scale pyroclastic flows associated with caldera forming events. However, the lithofacies of the Yamakogawa Rhyolite suggest emplacement from strombolian fire-fountains and pyroclastic flows with rheomorphism. These styles suggest the eruption of low viscosity magma, despite a rhyolitic composition. Similar cases are previously reported as extensive silicic lava (e.g., Bonnichsen and Kauffman, 1987), rheomorphic ignimbrite (e.g., Branney et al., 1992), and fountain-fed lava (e.g., Duffield, 1990). Eruption styles have been attributed to peralkaline composition (Mahood, 1984), high-magmatic temperature (Henry et al., 1989), low-water content (Creaser, 1991), and high-fluorine content (Duffield, 1990).

At the Yamakogawa Rhyolite, the chemical analyses (Table 1) show non-peralkaline composition (peralkaline is molecular $\mathrm{Na}_{2} \mathrm{O}+\mathrm{K}_{2} \mathrm{O} / \mathrm{Al}_{2} \mathrm{O}_{3}>1$ ). Moreover, presence of biotite is consistent with the non-peralkaline composition. An example of similar eruption style with non-peralkaline composition has also been reported (Chapin and Lowell, 1979; Henry et al., 1989; Branney et al., 1992). However, they document other mechanisms, which favor such eruption styles. These are high magmatic temperature and low-water content. The geothermometry of the Yamakogawa Rhyolite (Table 2) indicates that the magmatic temperature is not unusually high compared to typical rhyolitic magma. Spera (2000) showed that the eruption temperature for rhyolitic magma is generally $750-1000 \mathrm{C}$. This low temperature is consistent with occurrence of biotite in the entire units of the Yamakogawa Rhyolite. For example, Maaløe and Wyllie (1975) showed that biotite could not crystallize above approximately $880^{\circ} \mathrm{C}$ at $2 \mathrm{Kbar}$ for granitic magma, which 
is consistent with the composition and mineral assemblage of the Yamakogawa Rhyolite. Therefore, the Yamakogawa Rhyolite erupted at $<880^{\circ} \mathrm{C}$. Regarding water content, the primary value is difficult to estimate, because magmatic water escapes from magma during eruption, transportation, and after emplacement. However, biotite cannot be formed under low-water conditions. Its occurrence indicates high magmatic water content for the Yamakogawa Rhyolite.

\section{Conclusions}

1) The stratigraphy of the Yamakogawa Rhyolite is composed of seven units including lava flow deposits, nonwelded pyroclastic flow deposits, spatter-rich pyroclastic flow deposits, welded-agglutinate, and rheomorphic tuff.

2) These units were deposited from low-playing columns such as boil-over type pyroclastic flow or strombolian fire-fountains.

3) All the units of the Yamakogawa Rhyolite were erupted in conditions of non-peralkaline composition, lowmagmatic temperature and probably high magmatic water content.

In this report, we cannot constrain the conditions causing the eruption styles. However, we show that peralkaline composition, high-magmatic temperature and low-water content are not always required to produce low viscosity behavior in rhyolitic magma.

Acknowledgments. This work has greatly benefited from discussions with Katsuya Kaneko, Kazunori Watanabe, Tohru Danhara, and Hiroyuki Aso. We are grateful to Akira Hayashida for help of sampling in the field and Sharon Allen and Koji Uno for improving the manuscript. We acknowledge the Japan Marine Science and Technology Center (JAMSTEC) and Faculty of Science of Kyoto University for access to electron microprobe analyser and X-ray fluorescence analyser with help from Hiroshi Shukuno and Tomoyuki Kobayashi. We are indebted to Naoto Ishikawa for the use of the facilities. Thoughtful comments from Christopher Henry and Janet Sumner led to significant improvements to the paper. This research was supported in logistics by Aso Volcanological Laboratory, Kyoto University.

\section{References}

Aso, H. and K. Watanabe, The Haneyama Lava originated from pyroclastic flow distributed in the north-west Oguni town, Jour. Geol. Soc. Kumamoto, 79, 6-10, 1985 (in Japanese).

Bonnichsen, B. and D. F. Kauffman, Physical features of rhyolite lava flows in Snake River Plain volcanic province, southwestern Idaho, Geol. Soc. Am. Spec. Paper, 212, 118-145, 1987.

Branney, M. J. and B. P. Kokelaar, A reappraisal of ignimbrite emplacement: progressive aggradation and changes from particulate to non-particulate flow during emplacement of high-grade ignimbrite, Bull. Volcanol., 54, 504-520, 1992.

Branney, M. J., B. P. Kokelaar, and B. J. McConnell, The Bad Step Tuff: a lava-like rheomorphic ignimbrite in a calc-alkaline piecemeal caldera, English Lake District, Bull. Volcanol., 53, 187-199, 1992.

Cande, S. C. and D. V. Kent, A new geomagnetic polarity time scale for the late Cretaceous and Cenozoic, J. Geophys. Res., 97, 13,917-13,951, 1992.

Chapin, C. E. and G. R. Lowell, Primary and secondary flow structures in ash-flow tuffs of the Gribbles Run paleovalley, central Colorado, Geol. Soc. Am. Spec. Paper, 180, 137-154, 1979.

Creaser, R. A. and A. J. R. White, Yardea Dacite-Large-volume, hightemperature felsic volcanism from the Middle Proterozoic of South Aus- tralia, Geology, 19, 48-51, 1991.

Dingwell, D. B., C. M. Scarfe, and D. J. Cronin, The effect of fluorine on viscosities in the system $\mathrm{Na}_{2} \mathrm{O}-\mathrm{Al}_{2} \mathrm{O}_{3}-\mathrm{SiO}_{2}$ : implications for Phonolites, trachytes and rhyolites, Am. Mineral., 70, 80-87, 1985.

Duffield, W. A., Eruptive fountains of silicic magma and their possible effects on the tin content of fountain-fed lavas, Taylor Creek Rhyolite, New Mexico, Geol. Soc. Am. Spec. Paper, 246, 251-261, 1990.

Henry, C. D. and J. A. Wolff, Distinguishing strongly rheomorphic tuffs from extensive silicic lavas, Bull. Volcanol., 54, 171-186, 1992.

Henry, C. D., J. G. Price, D. F. Parker, and J. A. Wolff, Excursion 9A: MidTertiary silicic alkalic magmatism of Trans-Pecos Texas: rheomorphic tuffs and extensive silicic lavas, N. M. Bur. Mines Miner. Resour. Mem., 46, 231-274, 1989.

Hildreth, W., The Bishop Tuff: evidence for the origin of compositional zonation in silicic chambers, Geol. Soc. Am. Spec. Paper, 180, 43-75, 1979.

Holland, T. and J. Blundy, Non-ideal interactions in calcic amphiboles and their bearing on amphibole-plagioclace thermometry, Contrib. Mineral. Petrol., 116, 433-447, 1994.

Kamata, H., Stratigraphy and eruption age of the volcanic rocks in the west of Miyanoharu areas, Kumamoto Prefecture-Age and distribution of the volcanic activity of central-north Kyushu, Japan-, Jour. Geol. Soc. Japan, 91, 289-303, 1985 (in Japanese with English abstract).

Kamata, H., Volcanic and structural history of the Hohi volcanic zone, central Kyushu, Japan, Bull. Volcanol., 51, 315-332, 1989.

Kamata, H., Geology of the Miyanoharu district, Geol. Surv. Japan, 127 pp., 1997 (in Japanese with English abstract).

Maaløe, S. and P. J. Wyllie, Water content of a granite magma deduced from the sequence of crystallization determined experimentally with waterundersaturated conditions, Contrib. Mineral. Petrol., 52, 175-191, 1975.

Mahood, G. A. and W. Hildreth, Geology of the peralkaline volcano at Pantelleria, Straits of Sicily, Bull. Volcanol., 48, 143-172, 1986.

Mellors, R. A. and R. S. J. Sparks, Spatter-rich pyroclastic flow deposits on Santorini, Greece, Bull. Volcanol., 53, 327-342, 1991.

Nakada, S. and T. Fujii, Preliminary report on the activity at Unzen Volcano (Japan), November 1990-November 1991: Dacite lava domes and pyroclastic flows, J. Volcanol. Geotherm. Res., 54, 319-333, 1993.

Schmincke, H.-U. and D. A. Swanson, Laminar viscous flowage structure in ash-flow tuffs from Gran Canaria, Canary Islands, J. Geol., 75, 641-664, 1967.

Smith, T. R. and J. W. Cole, Somers Ignimbrite Formation: Cretaceous high-grade ignimbrites from South Island, New Zealand, J. Volcanol. Geotherm. Res., 75, 39-57, 1997.

Spencer, K. J. and D. H. Lindsley, A solution model for coexisting irontitanium oxides, Am. Mineral., 66, 1189-1201, 1981.

Spera, F. J., Physical properties of magmas, in Encyclopedia of Volcanoes, edited by H. Sigurdsson, 1417 pp., Acadenic Press, London, 2000.

Stevenson, R. J., R. M. Briggs, and A. P. W. Hodder, Emplacement history of a low-viscosity, fountain-fed pantelleritic lava flow, J. Volcanol. Geotherm. Res., 57, 39-56, 1993.

Sumner, J. M., Formation of clastogenic lava flows during fissure eruption and scoria cone collapse: the 1986 eruption of Izu-Oshima Volcano, eastern Japan, Bull. Volcanol., 60, 195-212, 1998.

Sumner, J. M. and M. J. Branney, The emplacement history of a remarkable heterogeneous, chemically zoned, rheomorphic and locally lava-like ignimbrite: 'TL' on Gran Canaria, J. Volcanol. Geotherm. Res., 115, 109138, 2002.

Turbeville, B. N., Tephra fountaining, rheomorphism, and spatter flow during emplacement of the Pitigliano Tuffs, Latera caldera, Italy, J. Volcanol. Geotherm. Res., 53, 309-327, 1992.

Valentine, G. A., F. V. Perry, and G. WoldeGabriel, Field characteristics of deposits from spatter-rich pyroclastic density currents at Summer Coon volcano, Colorado, J. Volcanol. Geotherm. Res., 104, 187-199, 2000.

Wolff, J. A. and J. M. Sumner, Lava fountains and their products, in Encyclopedia of Volcanoes, edited by H. Sigurdsson, 1417 pp., Acadenic Press, London, 2000.

Yamada, K., T. Tagami, and H. Kamata, Precise K/Ar geochronology of rhyolitic rocks in Hohi volcanic zone, central Kyushu island, Abstract of 2002 Japan Earth and Planetary Science Joint Meeting, Q037-P008, 2002 (in Japanese with English abstract).

K. Furukawa (e-mail: furukawa@gaia.h.kyoto-u.ac.jp) 